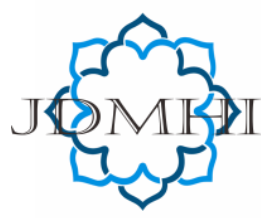

email: jdmhi@walisongo.ac.id

Journal of Digital Marketing and Halal Industry

ISSN: 2716-4810 (print) ISSN: 2716-4802 (online)

\title{
The Effect of Halal Certification, Halal Awareness and Product Knowledge on Purchase Decisions for Halal Fashion Products
}

\section{Arif Efendi}

Universitas Islam Negeri Walisongo Semarang, Indonesia

\section{A R T I C LE I N F O}

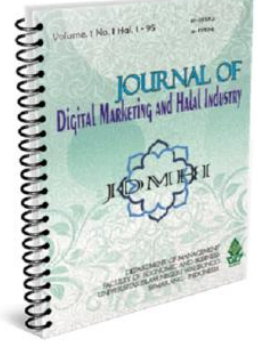

Article history:

Received 31 July 2020

Accepted 18 October 2020

Published 30 October 2020

Keywords:

Halal certification, halal awareness, product knowledge, purchase decision

\section{A B S T R A C T}

In this modern era, many companies produce fashion products labeled halal to increase sales value and increase public awareness about the importance of buying products tagged halal according to religious law. This study aims to examine the effect of halal certification, halal awareness and product knowledge on purchasing decisions for halal fashion products and provide a perspective on the importance of using halal products in society. This article type of research is quantitative; this journal's research data were obtained from 100 respondents who used halal fashion products in Semarang. The research data were analyzed using multiple linear regression. This article's research shows that halal certification has a positive but insignificant effect on fashion products' purchasing decisions labeled halal. Halal awareness has a positive and significant impact on product purchasing decisions. Product knowledge also has a positive and significant effect on purchasing decisions.

\section{@2020 Journal of Digital Marketing and Halal Industry}

\section{Introduction}

Indonesia is a country with a variety of ethnicities, cultures, customs, languages, and religions. This diversity is united and framed by the Unity in Diversity guidelines, which means that they are still one thing even though they are different. The variety of ethnic groups in Indonesia produces various unique items that can be commercialized, such as fashion, clothing, singing, dancing, culture, and food (Mubarok \& Imam, 2020). Different foods, cultures, and styles produced by tribes that were once considered the nation's wealth only enjoyed by the tribes themselves have now turned into tourism, which is now packaged by the government as halal tourism

\footnotetext{
* Corresponding author. email: arifafendi@walisongo.ac.id DOI: http://dx.doi.org/10.21580/jdmhi.2020.2.2.6160
} 
(Aini et al., 2020).

Based on the 2015 inter-census population survey (SUPAS) results, Indonesia's population in 2020 is 269.6 million. The total male population is 135.34 million, more than that of women, which is only 134.27 million. Indonesia is the world's largest Muslim country, with a Muslim population in 2010 reaching 209.12 million or about $87 \%$ of the total population. Then in 2020, Indonesia's Muslim population is estimated to reach 229.62 million. (www.bps.go.id). With such a large number of the Islamic population, this proves that Indonesia is a potential market for various producers of goods and services. Although each Muslim consumer has different compliance levels with sharia depending on their level of religiosity, Muslim consumers will have a different attitude. Positive towards products that use a halal approach in their marketing process (Aliman and Othman, 2007). Muslim consumers in Indonesia are looking for authentic halal certification issued by the MUI (Indonesian Ulama Council). This certification authorizes companies to use the halal logo printed on product packaging or displayed on the company's premises (www.halalmui.org).

According to Aziz and Vui (2013), halal certification is a guarantee of safety for Muslims to consume a product. This halal certification is proven by the inclusion of the halal logo on the product packaging. In general, the halal approach in the marketing process can also neutralize the negative image that Muslim consumers associate with a product (Salehudin and Lutfi, 2011). According to Shaari and Arifin (2010), halal awareness is the level of knowledge possessed by Muslim consumers to find and consume halal products according to Islamic law. According to Islamic law, Muslim understanding is characterized by knowledge of the process of slaughtering, food packaging, and food hygiene.

According to Peter and Olson (2014), product knowledge is consumer knowledge related to understanding product characteristics or characteristics, the consequences of using the product, and the satisfaction value that the product will achieve. Knowledge of consumer perceptions can help create and provide a halal product line that will meet the global market. Product knowledge can be a factor that influences consumer purchasing attitudes and behavior. According to Boyd Walker (2000), buying decision-making is an approach to solving consumers' activities to meet their wants and needs. According to Kotler and Armstrong (2000), several distinguishing factors influence purchasing behavior, including cultural, social, personal, and psychological factors that include consumer behavior, family, social status, income, lifestyle, knowledge, beliefs, attitudes, etc.

Several research results have been carried out, including research by Aziz and Vui (2013), Waskito (2015), and Ashari (2019), which state that halal certification has a positive effect on purchasing decisions. Halal certification protects consumers from doubts in using products, especially for Muslim consumers. As proof of the product, the halal label has been certified to be a source of product quality information. From the existence of a halal brand, consumers can get information that the product is guaranteed to be halal by the halal label's guarantor, namely MUI. The more someone knows that a product has halal certification, the more 
interested they will be with the product, so they decide to buy.

According to Yunus, Arifin, and Rashid (2014) and Waskito (2015), halal awareness has a positive and significant effect on purchasing decisions. Halal awareness is the level of understanding of Muslims in knowing issues related to the concept of halal. Awareness itself has been hypothesized as an important role in determining purchase intention. Halal awareness arises in exploratory interest, where the more consumers are aware of the importance of the concept of halal, the more consumers will seek information about these products. After consumers get enough information, consumers will use that information to foster attitudes and actions to buy these products, meaning that the higher their level of awareness of halal products, the higher their desire to buy.

According to Rahmawati (2014) and Ashari (2019), product knowledge positively affects purchasing decisions. Product knowledge is an important thing that must be communicated by marketers in providing directions for the products it offers to consumers. Marketers make various promotional efforts to provide education to consumers, especially in showing their products' advantages compared to competitors. Good product knowledge from consumers regarding the benefits of halal products will influence their decision to buy the product. This means that the higher and better someone's product knowledge of halal products, the higher their desire to purchase it.

Based on the above background, the purpose of this study is to test whether the variables of halal certification, halal awareness, and product knowledge affect purchasing decisions for halal fashion products in the city of Semarang.

\section{Literature Review}

\section{Halal Certification}

Halal certification guarantees safety for a Muslim consumer to choose food that is good for him and following religious rules. Food products that have a halal certificate are products that meet standards in safety and cleanliness in the processing process. According to Aziz and Vui (2013), halal certification guarantees security for Muslims to consume a product. This halal certification is proven by the inclusion of the halal logo on the product packaging. In general, the halal approach in the marketing process can also neutralize the negative image that Muslim consumers associate with a product (Salehudin and Lutfi, 2011).

According to the Decree of the Minister of Religion of the Republic of Indonesia Number 518, halal certification is a written fatwa stating the halalness of a food product issued by the Institute for the Study of Food, Drugs, and Cosmetics, the Indonesian Ulema Council (LPPOM MUI) (Amalia, 2019). Halal certification in Indonesia is officially issued by MUI, which indicates that a product has passed the halal test. According to Islamic law, products that have halal certification have been tested for their halalness and can be safely consumed by Muslims (Fataron \& Rohmah, 2019). Products that have halal certification are proven by including a halal logo on the product packaging.

According to Al-Quran, Surat Al-Baqarah verse 168 states the halal certification's basic 
principles are halal (permissible) and thoyyiban (useful). This illustrates that anything that enters the body must be legal according to Islamic law and benefit itself for Muslims in the world.

\section{Halal Awareness}

Social awareness is awareness of a social situation in a group or community in a particular environment. In this case, it can be tangible, intangible, or both. This includes rules made by humans, activities, positions, status, responsibilities, social connections, and the process of making groups in a short period to a long period in a social environment. Consciousness is the ability to understand, feel, and become aware of events and objects. Consciousness is a concept implying an understanding and perception of an event or subject (Aziz \& Vui, 2013). According to Ahmad, Abaidah, and Yahya (2013), halal awareness is known based on understanding whether a Muslim is halal, knowing the correct slaughtering process, and prioritizing halal food for their consumption. Based on the above understanding, it can be concluded that halal awareness is a Muslim knowledge of the concept of halal, the halal process, and considers that using halal products is essential for him.

According to Shaari and Arifin (2010) and Yunus, Arifin, and Rashid (2014), several factors become consumer awareness indicators in choosing halal products, including the following.

1. Halal raw materials are one of the essential factors that consumers must understand. A consumer in choosing his product must know the composition of the raw materials used to ensure a product's halalness.

2. Religious obligations The halalness of a product becomes a priority and a commitment for Muslim consumers in observing their religion. Therefore, the obligation to consume halal products is one of the benchmarks of Muslim consumers' halal awareness.

3. Production process One indicator of halal awareness is knowledge of the halalness of the production process. Understanding the production process can be known through television or internet media.

4. Product cleanliness Product hygiene is one of the benchmarks of halal awareness, which we can immediately look at the product.

5. Knowledge of international halal products. Halal awareness of a product is limited to understanding products available in the country, especially the products circulating in the market are not only products from within the land, but also foreign products have been circulating in the market. Therefore, knowledge of the existence of products originating from abroad is an indicator of halal awareness.

\section{Product knowledge}

According to Peter and Olson (2014), product knowledge is consumer knowledge related to product characteristics or characteristics, the consequences of using the product, and the value (level) of satisfaction the product will achieve. Product knowledge can be a factor influencing consumer purchasing attitudes and behavior. Experience definitively refers to a person's expertise and skills through a 
theoretical or practical understanding of a subject. Product knowledge can affect how consumers access a product. Said et al. stated that the knowledge variable could be divided into two, namely: objective experience, namely accurate information about the product stored in the long-term memory of consumers, and subjective knowledge, namely people's perceptions of what and how much they know about a product based on their interpretation. Understanding consumer perceptions can help create and provide a halal product line that will meet the global market.

\section{Purchasing decision}

According to Boyd Walker (2000), purchasing decision-making is an approach to solving problems in consumers' activities to meet their wants and needs. According to Kotler and Armstrong (2000), several characteristic factors influence purchasing behavior, namely

1. Cultural factors have the most extensive and profound influence on consumer behavior, including culture, sub-culture, and social class

2. Social factors related to behavior are also influenced by social factors such as small groups, family, role, and social status.

3. Personal factors related to consumer behavior are also influenced by emotional factors, namely age and life cycle stage, occupation, economic situation, lifestyle, personality, and self-concept.

4. Psychological factors related to consumer behavior are also influenced by psychological factors, namely, motivation (encouragement), perceptions, knowledge, beliefs, and attitudes.
According to Kotler in Afendi (2019), the buying decision-making process consists of five stages, namely

1. Introduction The problem related to the buying process starts when the buyer recognizes the problem or need. These needs arise from internal and external stimuli.

2. Information Search related to Consumers who are aroused by their needs will be motivated to seek more information. Mild information seeking situations are called attention reinforcement. And at a later stage, consumers may begin to actively seek information through reading materials and cellular telecommunications between friends or visiting shops to learn about specific products.

3. Alternative Evaluation is the stage where consumers form a very conscious and rational assessment of the product. Consumers use the information to evaluate alternative products within a group of choices. The attributes that consumers are interested in vary depending on the type of product.

4. Purchasing decisions are related to two factors, namely, internal factors and external factors. The inner aspect is the consumer's perception of the chosen brand. The consumer tends to select the brand they like. At the same time, external factors are the attitudes of other people and unexpected situations.

5. After-purchase behavior is related to behavior. After purchasing a product, consumers will experience a certain level of satisfaction or dissatisfaction. 
Consumer satisfaction or dissatisfaction with a product will influence subsequent behavior

\section{Hypothesis Development}

According to Aziz and Vui (2013), Waskito (2015), and Ashari (2019) state that halal certification has a positive effect on purchasing decisions. Halal certification protects consumers from doubts in using products, especially for Muslim consumers. As proof of the product, the halal label has been certified to be a source of product quality information. From the existence of a halal brand, consumers can get information that the product is guaranteed to be halal by the halal label's guarantor, namely MUI. The more someone knows that a product has halal certification, the more interested they will be with the product, so they decide to buy.

H1: Halal certification has a positive effect on purchasing decisions

According to Yunus, Arifin, and Rashid (2014) and Waskito (2015), halal awareness has a positive and significant effect on purchasing decisions. Halal awareness is the level of understanding of Muslims in knowing issues related to the concept of halal. Awareness itself has been hypothesized as an important role in determining purchase intention. Halal awareness arises in exploratory interest, where the more consumers are aware of the importance of the concept of halal, the more consumers will seek information about these products. After consumers get enough information, consumers will use that information to foster attitudes and actions to buy these products, meaning that the higher their level of awareness of halal products, the higher their desire to buy.

H2: halal awareness has a positive effect on purchasing decisions

According to Rahmawati (2014) and Ashari (2019), product knowledge positively affects purchasing decisions. Product knowledge is an important thing that must be communicated by marketers in providing directions for the products it offers to consumers. Marketers make various promotional efforts to provide education to consumers, especially in showing their products' advantages compared to competitors. According to Lin \& Lin (2007), product knowledge is an intrinsic guide that is very important for consumers to consider when evaluating products before making a purchase. Good product knowledge from consumers regarding the benefits of halal products will influence their decision to buy the product. This means that the higher and better someone's product knowledge of halal products, the higher their desire to purchase it.

H3: product knowledge has a positive effect on purchasing decisions.

\section{The Method, Data, and Analysis}

The type of data used in this study is primary data, data obtained from a questionnaire with 100 respondents. The sample in this study was consumers who bought halal fashion products (beauty products) in Semarang. Data analysis used in this research is quantitative Data, a form of Analysis using numbers and calculations with statistical tools. Research requires data analysis and interpretation that will be used to answer research questions so that data analysis can be more easily read and 
interpreted. The research hypothesis was tested using statistical tools in the form of SPPS.

\section{Result and Discussion}

\section{Multiple linear regression analysis}

This Analysis aims to determine the effect of the independent variable on the dependent Tabel.1

Multiple linear regression test

\section{Coefficients}

\begin{tabular}{|c|c|c|c|c|c|c|}
\hline \multirow[b]{2}{*}{ Model } & \multicolumn{4}{|c|}{$\begin{array}{ll}\text { Unstandardized } & \text { Standardized } \\
\text { Coefficients } & \text { Coefficients }\end{array}$} & \multirow[b]{2}{*}{$\mathrm{t}$} & \multirow[b]{2}{*}{ Sig. } \\
\hline & B & $\begin{array}{l}\text { Std. } \\
\text { Error }\end{array}$ & Beta & $\mathrm{t}$ & & \\
\hline 1(Constant) & 1,358 & 1,562 & & & ,869 & ,387 \\
\hline $\begin{array}{l}\text { Halal } \\
\text { Certification (X1) }\end{array}$ & , 134 & , 095 & & ,121 & 1,409 &, 162 \\
\hline $\begin{array}{l}\text { Halal Awareness } \\
\text { (X2) }\end{array}$ & ,619 & , 097 & &, 556 & 6,407 & ,000 \\
\hline $\begin{array}{l}\text { Product } \\
\text { Knowledge (X3) }\end{array}$ & ,247 & , 109 & & ,181 & 2,263 & ,026 \\
\hline
\end{tabular}

a. Dependent Variable: Purchasing Decision (Y)

Source: Primary Data, 2020

$\mathrm{Y}=1,358+0,134 \mathrm{X} 1+0,619 \mathrm{X} 2+0,247 \mathrm{X} 3$ $+\mathrm{e}$

Effect of halal certification on purchasing decisions

The regression test results state that halal certification has a positive but insignificant effect on purchasing decisions. This is evidenced by the $t$ value of 1.409 with a significance level greater than 0.05 or $\operatorname{sig} \mathrm{t}=$ $0.162>0.05$, so the above hypothesis is accepted. The results of this study are following the research of Aziz and Vui (2013), Waskito (2015), and Ashari (2019), which state that halal certification has a positive effect on purchasing decisions. Halal certification is a written fatwa made by the Indonesian Ulema Council (MUI) to declare the halalness of a product that is following Islamic law. This halal certificate requires obtaining a permit to include a halal label on a product package from an authorized agency. Meanwhile, individuals have different decision-making processes, depending on the thoughts and habits of consumers. Halal certification protects consumers from doubts in using products, especially for Muslim consumers. The halal label as proof of the product has been certified to be a source of information on product quality; from a halal brand, consumers can get information that the product is guaranteed to be halal by the halal label's guarantor, namely MUI. The more someone knows that a product has halal certification, the more interested they will be with the product, so they decide to buy. There is a positive but insignificant effect because halal certification is less of a concern to consumers because they do not understand or lack information about products that have included a halal label. For this reason, the government still needs to provide information about the halal brand to the community, especially Muslims (Rangkuti, 2010). According to Suryani (2008), only a few know about halal labels. The relationship between halal labels and purchasing decisions is minimal so that socialization from related 
institutions is needed about halal products to use. Also, Hawa (2007) states that the halal label on product packaging circulating in Indonesia is a logo with Arabic writing, which forms the word halal in a circle to allow consumers not to know.

\section{Discussion}

\section{The effect of halal awareness on purchasing decisions}

The regression test results state that halal certification has a positive and significant effect on purchasing decisions. This is evidenced by the $t$ value of 6.407 with a significance level greater than 0.05 or sig $t=$ $0.00<0.05$, the above hypothesis is accepted. This study's results are from research by Yunus, Arifin and Rashid (2014) and Waskito (2015), which state that halal awareness has a positive and significant effect on purchasing decisions. Halal awareness is the level of understanding of Muslims in knowing issues related to the concept of halal. Awareness itself has been hypothesized as an important role in determining purchase intention. Halal awareness arises in exploratory interest, where the more consumers are aware of the importance of the concept of halal, the more consumers will seek information about these products. After consumers get enough information, consumers will use that information to foster attitudes and actions to buy these products, meaning that the higher their level of awareness of halal products, the higher their desire to buy.

Effect of product knowledge on purchasing decisions

The regression test results state that product knowledge has a positive and significant effect on purchasing decisions. This is evidenced by the $t$ value of 2.263 with a significance level greater than 0.05 or sig $t=0.026<0.05$, so the above hypothesis is accepted. The results of this study are following the research of Rahmawati (2014) and Ashari (2019), which states that product knowledge has a positive effect on purchasing decisions. Product knowledge is an important thing that must be communicated by marketers in providing directions for the products it offers to consumers. Marketers make various promotional efforts to provide education to consumers, especially in showing their products' advantages compared to competitors. According to Lin \& Lin (2007), product knowledge is an intrinsic guide that is very important for consumers to consider when evaluating products before making a purchase. Good product knowledge from consumers regarding the benefits of halal products will influence their decision to buy the product. This means that the higher and better someone's product knowledge of halal products, the higher their desire to purchase it.

\section{Test the whole model (Test F)}

Table F Test

ANOVA

\begin{tabular}{cccccc}
\hline Model & $\begin{array}{c}\text { Sum of } \\
\text { Squares }\end{array}$ & df & $\begin{array}{c}\text { Mean } \\
\text { Square }\end{array}$ & F & Sig \\
\hline Regression & 2029,490 & 3 & & & \\
Residual & 1711,260 & 96 & 676,497 & 37, &, $000^{\mathrm{h}}$ \\
Total & 3740,750 & 99 & 17,826 & 951 & \\
\hline
\end{tabular}

Source: Primary Data:2020

From the results of the regression test above, it can be seen that the $\mathrm{F}$ probability value of 0.000 is smaller than the significance level of 
0.05, so it can be concluded that the estimated regression model is suitable to be used to explain the research variables.

Table.3 Determination Test

\begin{tabular}{ccccc}
\hline Model & $\mathrm{R}$ & $\mathrm{R}$ Square & $\begin{array}{c}\text { Adjusted R } \\
\text { Square }\end{array}$ & \\
\hline 1 &, $737^{\mathrm{a}}$ &, 543 &, 528 & 4,222
\end{tabular}

Source: Primary Data:2020

This study's adjusted R Square value is 0.528 , meaning that the purchasing decision variable can be influenced by halal certification, halal awareness, and product knowledge by $52.80 \%$. In comparison, other variables explain the remaining $47.2 \%$ outside of the study.

\section{Conclusion}

Based on the research results that have been done, it can be concluded that halal certification has a positive but insignificant effect on purchasing decisions. Halal awareness has a positive and significant impact on purchasing decisions, meaning that the higher a person's level of understanding of halal products, the higher their desire to buy. Product knowledge has a positive effect on purchasing decisions, meaning that the higher and better someone's product knowledge of halal products, the higher their desire to buy and use it. Meanwhile, this study's adjusted R Square value is 0.528 , meaning that the purchasing decision variable can be influenced by halal certification, halal awareness, and product knowledge by $52.80 \%$. In comparison, other variables explain the remaining $47.2 \%$ outside of the study.

\section{Recommendation}

Some suggestions that researchers can convey are that it is better to test in further research by increasing the number of research samples to get better results. Furthermore, adding several research variables such as religiosity, brand, price, foodstuffs, etc. It is better to use other objects outside of this research to describe the halal topic more fully in further study.

\section{References}

Afendi, A. (2019). Peran Green Trust Dalam Memediasi Pengaruh Green Perceived Value Dan Green Perceived Quality Terhadap Green Purchase Behavior. Optimum, 9(1).

Ahmad, N. A., Abaidah, T. N. T., \& Yahya, M. H. A. (2013). A study on halal food awareness among Muslim customers in Klang. 1073-1087.

Aini, N., Ardiani, F., \& Hanastiana, M. R. (2020). Halal Food Industry: Challenges And Opportunities In Europe. Journal of Digital Marketing and Halal Industry, 2(1), 43-54.

Aliman, N.K. dan Othman, M. . (2007). Purchasing Local and Foreign Brands: What Product Attributes Metter? Proceedings of the 13th Asia Pacific Management Conference, Melbourne, Australia, 400-411.

Amalia, F. (2019). The Role of Religiosity on Halal Product Purchasing Decision Case Study: Wardah Cosmetics. Journal of Digital Marketing and Halal Industry, 1(1), 19-24.

https://doi.org/10.21580/jdmhi.2019.1. 1.4774

Ashari, M. (2019). Pengaruh Pengetahuan Produk Dan Sertifikasi Halal Terhadap 
Keputusan Pembelian Produk Farmasi Di Desa Mojorejo Kecamatan Kebonsari Kabupaten Madiun. Universitas Islam Negeri Sunan Ampel Surabya.

Aziz Y.A. dan Vui C.N. (2013). NoThe Role of Halal Awareness, Halal Certification, and Marketing Components in Determining Halal Purchase Intention Among Non-Muslims in Malaysia: A Structural Equation Modeling Approach Title. Journal of International Food and Agribusiness Marketing, 25(1), 1-23.

Boyd, Walker, L. (2000). Manajemen Pemasaran Suatu Pendekatan Strategis dengan Orientasi Global (2nd ed.). Erlangga.

Departemen Agama RI. (2008). Al Qur'an dan terjemahan. Diponegoro.

Fataron, Z. A., \& Rohmah, H. (2019). Effect Analysis of Trust, Ease, Information Quality, Halal Product on Online Purchase Decision of 2016-2018 Batch Students of Islamic Economics Study Program in UIN Walisongo at Shopee Marketplace. Journal of Digital Marketing and Halal Industry, 1(1), 1-18. https://doi.org/10.21580/jdmhi.2019.1. 1.4772

Hawa. (2007). Label Halal. Islahi.

Kotler dan Armstrong. (2000). Dasar-dasar Pemasaran. Prenhallindo.

Lin, N \& Lin, B. (2007). The Effect of Brand Image and Product Knowledge on Purchase Intention Moderated by Price Discount. Journal of International Management Studies.

Mubarok, F. K., \& Imam, M. K. (2020). Halal Industry in Indonesia; Challenges and Opportunities. Journal of Digital
Marketing and Halal Industry, 2(1), 55-64.

Peter J. Paul dan Jerry C. Olson. (2014). Perilaku Konsumen dan Strategi Pemasaran. Salemba Empat.

Rahmawati, V. (2014). Pengaruh Atribut Produk dan Label Halal sebagai ariabel Moderating terhadap Keputusan Pembelian Produk Kosmetik Wardah di Kota Semarang. Jurnal Fakultas Ekonomi Dan Bisnis Universitas Dian Nuswantoro, $1-9$.

Rangkuti, F. (2010). Strategi Promosi dan Kreatif. Gramedia Utama.

Salehudin,I.danLuthfi, B. . (2011). Marketing Impact of Halal Labeling toward Indonesian Muslim Consumer's Behavioral Intention. ASEAN Marketing Journal, 3(1).

Shaari, J. A. N. And Arifin, N. S. (2010). Dimensi of Halal Purchase Intention: A Preliminary Study. International Review of Business Research Papers, 6(4), 444-456.

Suryani, T. (2008). Perilaku Konsumen Implikasi pada Strategi Pemasaran. Graha Ilmu.

Waskito, D. (2015). Pengaruh Sertifikasi Halal, Kesadaran Halal, Dan Bahan Makanan Terhadap Minat Beli Produk Makanan Halal. Uny, 1, 1-12. https://doi.org/10.1017/CBO97811074 15324.004

Yunuz M., Rashid W., Ariffin M., \& R. M. (2014). Muslim's Purchase Intention Towards Non-Muslim's Halal Packaged Food Manufacturer. Procedia - Social And Behavioral Sciences, 145-154.

www.bps.go.id

www.halalmui.org 